\title{
Media Effect into Conflict Management: A Comparative Study on Israel and Palestine Media Practitioners View Point
}

\author{
Ibrahim T. I. Ukka1', Hong Yu², Bienmali Kombate ${ }^{3}$ \\ ${ }^{1}$ Ph.D. Candidate at School of Journalism and Information Communication, Huazhong University of Science and Technology, \\ Wuhan, China \\ ${ }^{2}$ Prof. of Communication and Journalism at School of Journalism and Information Communication, Huazhong University of \\ Science and Technology, Wuhan, China \\ ${ }^{3} \mathrm{Ph}$.D. Candidate at College of Public Administration and Faculty of Economics and Management Member at University of Lomé, \\ Huazhong University of Science and Technology, Wuhan, China \\ Email: ibrahimokah@hust.edu.cn, bienmali41@hust.edu.cn
}

How to cite this paper: Ukka, I.T.I., Yu, H. and Kombate, B. (2019) Media Effect into Conflict Management: A Comparative Study on Israel and Palestine Media Practitioners View Point. Open Access Library Journal, 6: e5984.

https://doi.org/10.4236/oalib.1105984

Received: December 9, 2019

Accepted: December 27, 2019

Published: December 30, 2019

Copyright $\odot 2019$ by author(s) and Open Access Library Inc.

This work is licensed under the Creative Commons Attribution International License (CC BY 4.0).

http://creativecommons.org/licenses/by/4.0/

\begin{abstract}
The paper aimed to test the media effect limited theory versus the media non-limited effect theory and to understand the implication and impact of political will through media into a conflict management. Israel and Palestine conflict was used as a case study and a sample of 153 respondents (including 67 from Israel and 86 Palestinians) was collected and the survey questionnaire was administered through online, however, the study participants were extracted through a population of media practitioners based on convenient sampling method. The study finding concluded that the theory limited effect of media is verified. Media are influenced by political leaders in their report during the conflict.
\end{abstract}

\section{Subject Areas}

International Relations, Journalism and Communication, Politics

\section{Keywords}

Media, Conflict, Politic, Media Limited Effect, Media Non-Limited Effect

\section{Introduction}

Media especially through the print media gained its importance in the life of the political systems from the nineteenth century, however, with the arrival of radio and television, during the twentieth century, they know their greatest develop- 
ment. Considered as a fourth power, media are coveted and feared. Political actors often give them a great influence because of the important social visibility they offer. The reality seems quite different, however, according to most sociological studies, because if the media play a role in soliciting emotion or in the agenda of certain subjects, audiences cannot passively pass the opinions they help to disseminate. Media effect is no longer limited to strengthening opinions and attitudes, but has become an important agent of socialization, creating and shaping the minds and habits of society. Since the 1940s, researchers in the mass media have wondered about the effects of the media and how they affect our lives at different levels. But the opinions of researchers differ: there are essentially two theses: the first asserts that the media shape society and influence its attitudes and the second attributes that the media have a passive role indicating that their influence is limited.

Early research on the power of the media focuses on how propaganda can affect individuals as example in propaganda technique in World War I [1], and proposes a model of functional analysis called the model of the hypodermic syringe. The work presents receivers as passive and incapable of refusing or resisting messages transmitted. A propagandist can thus content himself with spreading his message in order to be able to act on the behavior of the individuals. However, it must first ask a series of questions in order to adapt its communication action to the context such as: 1) who says what: we must study the motivation and the message of the issuer, 2) by which channel: the broadcasting techniques by which the message transits (radio, press, TV, etc.), 3) who: analysis of audiences by age, sex, etc, and 4) with what effect: it is to determine the influence of the message on the audience.

While Lasswell's model views communication as a dynamic process with a sequence of steps, he conceives of communication solely in terms of influence and persuasion. It does not take into account the possibility of feedback or the context of receiving the message. In The Rape of the Crowds by Political Propaganda [2], there also asserts that political power can indoctrinate the masses through propaganda. His study feeds on the theory of the psychologist Ivan Pavlov who worked on conditioned reflexes in animals. Therefore, to understand the effect of media, this study examined whether media practitioners from different countries could be influenced by political power paten in covering a geopolitical conflict. The paper also intended to apprehend how media coverage is influenced by different countries' media systems and media sources. The Israel and Palestinian geopolitical conflict is an important international incident that so far takes it source in political difference. While there are more than a thousand, including international and local media, reports covering this controversy conflict, which has attracted attention all over the world. But, previous mass communication research shows less attention to comparative, cross-political studies. Thereby, this paper aimed on two different countries' media practitioner view point, Israel and Palestine media practitioner. 


\section{Theories of Media Effect}

The quarrel over the effects big or small of the media can be conceived as well. "The theory of limited effects," some say, is a convenient alibi, a way to wipe out the daily ravages of the media. The "theory of powerful effects", the others say, is purely and simply a matter of fabulation. It is a "madness of grandeur" prosaically underpinned by the desire of researchers to establish their legitimacy by making themselves the exorcists of an imaginary curse. It is probably useful to present here a less caricatural version of this debate based on a brief description of the paradigm of limited effects and especially on the formulations proposed by its main representative since [3] and one of his most virulent critics [4].

From a historical point of view, the theory of "limited effects" is presented as the refutation of another theory: the "hypodermic syringe" theory. Both theory of society and a theory of the role played by the mass media where Society is a society of masses. The media inject ideas, attitudes, and patterns of behavior to atomized, passive, and particularly vulnerable individuals. In developing and codifying the alternative that they propose, "Katz and Lazarsfeld explicitly aim to dethrone the model of the syringe by placing in their social environment the recipients of the messages of the media. Essential articulation of the new paradigm, the model of two stages of the flow of communication gives "opinion leaders" a decisive role of constituting relays or mediations between the messages of mass communications and the public. Suggested in conclusion of The People's Choice [5], the model of the "two stages" is developed in Personal Influence, [5] which constitutes the official birth certificate, reaches its canonical form in effects of mass communications [6], and thus influences most American research on the effects of mass media.

From this model, Katz summarizes the essential point by emphasizing that we must take into account to "defense mechanisms put into play by an audience capable of selectivity in the reception, perception and retention of messages, and the context of the formation of opinions and attitudes, conceived in terms of networks of interpersonal relationships [7]. The study of these variables reveals very early, that the influence of the media is far from being total (selective reception), far from being direct (interpersonal mediation, selective perception), far from being immediate (time required by the influence process along interpersonal networks). Marking limited media influence, the notions of individual selectivity and interpersonal mediation open the field of research to a theoretical perspective from social psychology. "The introduction of this perspective is, according to Gitlin, a turning point". As always in sociology, the questions asked and the field they draw, define a paradigm before even appear answers and results.

The work of Lazarsfeld and his collaborators thus inaugurates a tradition obsessed by the problem of the "variables" which intervene between producers and receivers of a message, and in particular by that constituted by interpersonal relations. The media then become variables among others. Their effects are posited as comparable and commensurable with those of other variables. "For Gitlin 
such an approach consists in evacuating the problem instead of explaining it". Constituted as official dogma of the sociology of the media, the theses of Personal Influence are to highlight the resistance of the public to the messages produced by the media, and to ignore their docility and passivity vis-à-vis them. Katz emphasizes, as an answer, the contradiction between the immense power granted to the media, and the very modest one that the effects studies attest to, and this, all along the forty years since Personal influence.

If the power of the media is immense, how is it that it escapes any empirical verification? The paradox is not only polemical. Katz concedes that it is not only a question of denouncing the mythomania of powerful effects. We must also question the nature of the criteria that empirical researchers assign to the phenomena they study in accepting the idea that they do not always have an adequate conceptualization of these and that the sheer scale of certain phenomena can lead to their being masked. He then proposes "the following three complementary research objectives: 1) To define in all their complexity the influence processes put into play by the media. Identify precisely the variables that intervene between a given message and the effects that are expected. 2) Avoid a shackles of restrictive definitions that would exclude or conceal entire sections of the power of the media. 3) Justify the relevance of the methods chosen to evaluate these effects."

In his book "Media Effect", [8] is right in presenting these three goals as complementary, and they are in his own practice. It should be noted, however, that historically they have represented distinct options. The evolution of American research in this area can be read in the perspective of a conflict between the first objective of the program and the other two. The first goal leads to the theory of limited effects, very early formed into a "dominant paradigm". The other two are related to the questioning of this paradigm, to a criticism of its "restrictive definitions", and to a rejection of the methodological censorship imposed by the nature of the criteria retained.

\section{Influence of Political Power in Media Report}

[9], in his book, Grenoble University Press, Coll. "Politics and more" is interested in the power of the media and the relationship between the political field and the media. Western societies have experienced in recent decades the rise of the media. This is manifested by the enthusiasm of households for the acquisition of new communication devices, by the high consumption of television programs as well as by the increase in use of websites and digital networks. These upheavals also affected the political field, which had to adopt specific techniques and modes of operation dictated often by the media, the pollsters and the communication advisers. In the first part of the book, the author reviews the work done on the power of the media in the mainstream of media sociology. Derville was not limited to a simple chronological enumeration of the different theoretical currents, he also highlighted the points of convergence and the breaks between them. He explains that the sociology of the media has developed to measure the 
impact of the media on the public. It goes without saying that the history of media sociology challenges the paradigm of the powerful effects and omnipotence of the media. Lazarsfeld's work, experiences in psychosociology and reception studies have shown that the influence of the media depends on the insertion of individuals into social groups, their psychological predispositions, their expectations and satisfactions, as well as their codes, from which they interpret the messages received.

In chapter 2 of the first part, the author explains that the effect of the media on the public should not be analyzed restrictively by equating influence with efficiency, because there are in fact several forms of influence policy. The news media help to increase the level of information of the public, they can modify their stock of knowledge; they can influence their visions of the world, their reasoning. However, these same media are able to direct the public's attention to specific issues and thereby prioritize; this is the concept of agenda-setting proposed by [10]. By exposing themselves to the news media, individuals are "less likely to set in motion the defense mechanisms described by the paradigm of limited effects [11], they view these media as producers and disseminators of information and not as propaganda vectors. The media messages conveyed are therefore more influential, because they affect the cognitive aspect and can even exert an evaluative or even conative influence. The agenda-setting theory has the merit of pointing out that the influence of the media goes beyond their role as information transmitter, but lies in their ability to structure the concerns and knowledge of the public. By failing to tell people what to think, the media is able to tell the public "what to think about" by mediating some issues rather than others. Although attractive, the agenda-setting hypothesis did not have very clear empirical confirmation [12]. The empirical results from this paradigm have shown the limits of this theory, as evidenced by the survey conducted by Ray Funkhouser in the United States in 1960 on the relationship between the media, public opinion and real events Funkhouser has It has been shown that there is a relationship between the degree of public concern expressed about certain themes and the amount of information the media has devoted to these topics. However, the meaning of the causality has not been verified. Is it the media that draws the attention of the public to certain subjects and which is at the origin of the evolution of the public opinion vis-a-vis these subjects? Or, on the contrary, does the media simply reflect the concerns of the people? Admittedly, the issue of agenda-setting has the merit of reminding us that the influence of the media lies not only in the transmission of information from a persuasive perspective, but also in their ability to prioritize the concerns and knowledge of the public. The empirical results, however, seem more disappointing and do not allow to generalize the results advanced in 1972 on the ability of the media to structure public opinion.

In 1991, Shanto Iyengar's book poses a new problem that complements the concept of agenda-setting; it is the concept of framing, which is to present in a particular way each of the topics covered in the media. The choice of words, metaphors, and images by journalists contributes to shaping public opinion on 
certain social and political issues and thereby fosters certain ideological and political currents. Through the framing effect, the media tries to guide the public's judgment on a theme without explicitly enjoining it to adopt a certain behavior or a certain opinion. This phenomenon of framing shapes our categories of perception and contributes to the construction of the reality that surrounds us. "The media is helping to popularize, amplify and crystallize the social stereotypes that circulate in the social body about certain categories of people, and in particular, negative stereotypes". According to [13], the decoding of the world is done according to "typifications" which consist of simplified representations of certain categories of individuals (politicians, workers, young people, Arabs, etc.) which allow to apprehend them quickly and systematically. The media sort out the events that occur in the world and select those that seem worthy of being publicized according to certain professional and technical criteria, but also according to ideological interests more or less closely related to interests. economic or social. In the end, Derville notes that "we are not in contact, through the media, with the world, but only with certain fragments of the world, which are more particularly approached from a particular angle" (p.69). Thus, by drawing attention to certain facts and speeches, the media convey a particular image of reality that can favor certain groups over others by conveying and legitimizing their ideas and actions. After the effect of calendar-setting and the framing effect, another mechanism highlighted by [14] demonstrates the influence of the media on the judgment of the public; this is the priming effect of evaluating parties and political actors from the position they take on the theme in question.

However, Derville emphasizes the power of the media to accentuate the disparities between social and cultural groups, as Philip Tichenor, George Donohue and Clarice Olien put it so well through the concept of the knowledge gap in 1970. Indeed, people more socioculturally favored people tend to be better equipped with communication technologies, they are better informed, they are more attentive to the information they receive, they are more critical of the media than are the members of disadvantaged groups. The new information and communication technologies, and in particular the Internet, seem to accentuate the knowledge gap phenomenon even more, since Internet users have a particular profile: they are generally younger, rather masculine, and they have a high cultural and academic capital. Derville explains that the reasons for this social fracture are primarily economic. In fact, computer equipment and unlimited access to the Internet represent high costs for some, especially for people living in rural areas. However, other factors favor this digital divide; it's about sociocultural factors. The use of the Internet and new technologies requires mastery of certain skills in computer science, English, writing and writing, but especially skills in terms of management and information processing. The continuous flow of information on the Internet can confuse individuals in their quest for reliable and relevant information and can "provoke the inhibition of the citizen or make it impossible for him to decide" [15]. The early 1970s were marked by a resur- 
gence of critical studies. The defenders of this current address several criticisms of the dominant paradigm of limited effects, "firstly because of the too restrictive conception of the influence it adopts, but also and above all because of its conservatism on the social and political level" (p. 73). According to this critical current, not only are individuals enrolled in primary groups, but they also belong to broad social groups (social classes) that largely shape their expectations of the media and their reactions to the messages they receive. These social groups are not represented in the same way in the media. Some are excluded or marginalized, while other groups with greater political, economic, cultural and symbolic resources dominate and impose their ideas and worldviews. But, Contrary to previous research trends that only consider the effects of political content, the current of cultural studies believes that cultural domination can be exercised through media content that seems to be the only entertainment such as varieties, serials, advertising or sports retransmissions. This type of program provides a framework for interpretation of reality, models of thought and interpretation that can influence certain segments of the public. In the current media context where information mixes with entertainment and where debate becomes a spectacle, the contribution of cultural studies seems even more relevant, especially with the explosion of the Internet. Other researchers, [16] have studied the contribution of the media to the formation and transformation of individual and collective identities. Through entertaining programs, socially valued models of thought and action are offered to individuals and can help build, strengthen or evolve their individual identities.

\section{Methodology}

In order to analyse the effect of media, the research data was collected with total sample size of 153 participants including 67 from Israel and 86 from Palestine through online survey questionnaire using the Likert 5 points scale which is commonly use in social science to allow the participants to have multiple choices and choose the response accordingly. This process was completed during the period of August 2018 to February 2019 which included finding potential respondent, initial communication, sending the questionnaires and follow up. However the convenient sampling method was used in choosing the research respondents and the study population was media practitioner. Participant were contacted conveniently to solicit them to answer the survey questionnaires through journalists online Forum from both side, Israel and Palestine and on other social media such as facebook, linkedin, and email.

\subsection{Operationalization of Variables}

In this study, variables such conflict was used as dependent variable, media as independent variable which lead to know the direct effect or effect complet of media on conflict management. However, Political influence was used as mediating variable leading to compute the indirect effect or the limited effect of 
media on conflict management.

\subsection{Control Variable}

Even though political power has a significant influence on media, each country political power is subjective with its politicians political will. Therefore, to check the difference among Israel and Palestine political power influence on media, the study used the "country" as a control variable and to analyse, a dichotomic coding was applied using 1 for the country Israel and 2 for the country Palestine.

\subsection{Research Model}

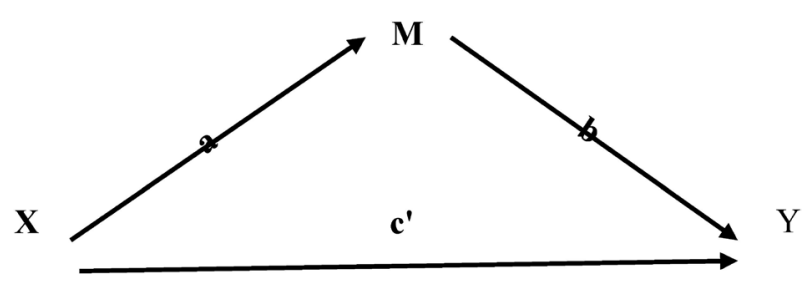

Mediation Model by [17]

M: intervening or process variable

$X$ : causal variable

$Y$ : outcome variable

$a b$ : indirect effect

$c !$ direct effect

$(a b+c):$ total effect

\section{Finding and Discussion}

To measure the effect of media on conflict management, a regression analysis was applied to compute pearson correlation between media and conflict.

The correlation between media and conflict $(\mathrm{r}=0.451)$ as shown in Table 1 is statically significant at 95\% degree of confidence. However, $r=45.1 \%<50 \%$ mean that there's a weak influence of media in conflict management. This finding confirm that the role of media remain as surveillance, interpretation, linkage,

Table 1. Pearson correlations results.

\begin{tabular}{cccc}
\hline Element & & Conflict & Media \\
\hline \multirow{2}{*}{ Pearson Correlation } & Conflict & 1.000 & 0.451 \\
& Media & 0.451 & 1.000 \\
& Conflict & $\cdot$ & 0.000 \\
Sig. (1-tailed) & Media & 0.000 & $\cdot$ \\
& Conflict & 148 & 148 \\
& Media & 148 & 148
\end{tabular}

Source: data field 2019. 
transmission of values and entertainment, [18] and [19], but in contradiction [20] [21] and Price and [22] concluded their studies that media have a strong influence on conflict management and contributing in winning the heart and mind of the society. [23]. added that media into conflict creat division by not reflecting the pluralism of the political and social structure. However, the study finding came into supporting the previous literatures such as [22] and [24] in their study regarding the role of media into conflict management concluded that media are promoting peace with a positive effect.

Also, the research finding shown in Table 2 below with coefficient of determination (adjusted $\mathrm{R}^{2}$ ) $=0.198$ or $19.8 \%<50 \%$ which mean that the variable media can explain only $19.8 \%$ of the conflict management, therefore, the first theory which labelled that media have a strong influence on conflict management is not verified.

To check how the political power and/or how politician influencing media in their report, we use the variable political power as mediating variable between media and conflict. And the stoical tool process version 3.3 written by [25]. is applied to analyse the effects both direct and indirect effect of media throut Political power on conflict.

After followed the strick 4 steps defined by [26] [27] and [28] in mediation analysis, the finding included in Table 3 shown that the indirect effect $(a b)=$ $0.2556 \%$ or $25.56 \%$ is greater that the direct effect $\left(c^{\prime}\right)=0.0881 \%$ or $8.81 \%$ which means that there was a perfect mediation. Hence, the study concluded that media have a limited effect on conflict management as the influence of media through political power, the intervening factor (indirect effect) is greater that the direct influence of media on conflict (direct effect), therefore, the theory of media have a limited effect is verified.

Table 2. Model summary.

\begin{tabular}{|c|c|c|c|c|c|c|c|c|c|}
\hline \multirow[b]{2}{*}{ Model } & \multirow[b]{2}{*}{$\mathrm{R}$} & \multirow[b]{2}{*}{ R Square } & \multirow{2}{*}{$\begin{array}{l}\text { Adjusted } \\
\text { R Square }\end{array}$} & \multirow{2}{*}{$\begin{array}{l}\text { Std. Error of } \\
\text { the Estimate }\end{array}$} & \multicolumn{5}{|c|}{ Change Statistics } \\
\hline & & & & & $\begin{array}{l}\text { R Square } \\
\text { Change }\end{array}$ & F Change & df1 & $\mathrm{df} 2$ & $\begin{array}{c}\text { Sig. } \\
\text { F Change }\end{array}$ \\
\hline 1 & $0.451^{\mathrm{a}}$ & 0.203 & 0.198 & 2.96745 & 0.203 & 37.286 & 1 & 146 & 0.000 \\
\hline
\end{tabular}

a. Predictors: (Constant), Media; b. Dependent Variable: Conflict.

Table 3. Total, direct, and indirect effect of media on conflict through political power.

\begin{tabular}{ccccccccc}
\hline $\begin{array}{c}\text { Total effect } \\
\text { of X on Y }\end{array}$ & Effect & Se & $\mathrm{t}$ & $\mathrm{P}$ & LLCI & ULCI & c_ps & c_cs \\
\cline { 2 - 9 } & 0.3437 & 0.0571 & 6.0149 & 0.0000 & 0.2308 & 0.4567 & 0.1036 & 0.4481 \\
\hline $\begin{array}{c}\text { Direct effect } \\
\text { of X on Y }\end{array}$ & Effect & Se & $\mathrm{t}$ & $\mathrm{P}$ & LLCI & ULCI & c_ps & c_cs \\
\cline { 2 - 8 } & 0.0881 & 0.0580 & 1.5207 & 0.0130 & -0.0264 & 0.2027 & 0.0266 & 0.1149 \\
\hline $\begin{array}{c}\text { Indirect effect (s) } \\
\text { of X on Y }\end{array}$ & Effect & & BootSE & BootLLCI & BootULCI \\
\cline { 2 - 8 }
\end{tabular}

Y: Conflict, X: Media, and M: Politic. Source: data field 2019. 
Table 4. Independent sample t-test analysis.

\begin{tabular}{ccccccc}
\hline & Country & Mean & Std. Deviation & Std. Error Mean & $\mathrm{t}$ & $\mathrm{df}$ \\
\hline \multirow{2}{*}{ Media } & Israel & 15.1212 & 4.16400 & 0.51255 & & \\
& Palestine & 16.0714 & 4.44453 & 0.48494 & 1.985 & 148 \\
\multirow{2}{*}{ Politic } & Israel & 31.0154 & 8.26607 & 1.02528 & & \\
& Palestine & 33.2317 & 6.09655 & 0.67325 & & \\
\hline
\end{tabular}

Source: data field 2019.

To check the cross media influence on the outcome variable (conflict), independent Sample t-test was conducted. The results in Table 4 show that media and political power have an impact on conflict management. The independent Sample $\mathrm{t}$-test found that media in Israel with $\mathrm{M} \%=15.12, \mathrm{SD}=4.16$ is less than media in Palestine with $\mathrm{M} \%=16.07, \mathrm{SD}=4.44$ both at $\mathrm{t}=1.985$ and the $\mathrm{p}$-value is 0.0490 less than 0.05 at two taile. Consequently, Palestine media influencing more into the geopolitical conflict than Israel media.

Likewise, the results of the independent Sample t-test to check the cross political impact on the conflict show that Israel politicians influencing on media with $\mathrm{M} \%=31.06, \mathrm{SD}=8.27$ is less that Palestine politician with $\mathrm{M} \%=33.23$, SD $=6.10$ both at $\mathrm{p}$-value is 0.0388 less than 0.05 . Thus, Palestine politicians influence media in their report on the geopolitical conflict more that Israel politicians.

\section{Conclusion and Implications}

The finding in this paper contributed to the growing of the literature in media study, specially in the field of media effect. It's not surprising that the results of this study show that the correlation between media and conflict is weak (Pearson correlation $r=45.1 \%<50 \%)$. But, the finding also highlighted that only $19.8 \%$ of the geopolitical conflict can be explained by media or i.e. conflict can be predicted on $19.8 \%$ by the media. For the story that raised may cause contradictions between media researchers and scholars, the two theses, such as limited effect of media theory influenced into conflict management, the finding of this study through the results of process analysis, come to conform that media have a limited effect into conflict management that the direct effect $\left(c^{\prime}\right)=0.0881$ is less than the indirect effect $(a b)=0.2556$.

As it's complex to understand the role played by political powers through media into conflict management in two different nations, the cross political study applied with the independent Sample t-test shows that the political will of Palestine politicians impacts much on Palestine media in their conflict report of Israeli Politicians.

However, the study focused only on media practitioners as study population and drew the comparison based on the respondents feeling. As participants in this study from both countries Israeli and Palestine are coming from different background in culture, education, social, and different professional experience. 
Therefore, this study apparently grieves from some limitations. In view of the limitations outline above in this section, this research needs a support from future researches to carry out a cross-study taking into account the outline variable as mediation or control variable. When comparing two countries like Israel, a Jewish state and Palestine, an Arab state which since 15 December 1988 declared its independence of November 1988 but wasn't mandated by UN general assembly with resolution 43/177 till the 3 August 2018, 137 (71\%) of the 193 member states of the United Nations have approved it as a Palestine State. The differences do not arise only on the political will, but the national interest. Also, this study suggests an assessment of how political and media systems impact news construction, transmission and development. As [29] argued that comparative analysis is appreciated in social study, since it explains us to variation and to similarity which can underwrite powerfully to concept development and to the improvement of our conceptual apparatus.

\section{Conflicts of Interest}

The authors declare no conflicts of interest regarding the publication of this paper.

\section{References}

[1] Lasswell, H. (1927) The Theory of Political Propaganda Harold D. Lasswell. Political Science, 21, 627-631. https://doi.org/10.2307/1945515

[2] Tchakhotine, S. (1988) Le viol des foules par la propagande politique. 605.

[3] Blair, J. and Lacy, M.G. (1993) From the SAGE Social Science Collections. Rights Reserved. The Annals of the American Academy of Political and Social Science, 503, 122-136.

[4] Gitlin, T. (1978) Media Sociology: The Dominant Paradigm. Theory and Society, 6, 205-253. https://doi.org/10.1007/BF01681751

[5] McClung Lee, A. (1949) LAZARSFELD, PAUL F., BERNARD BERELSON, and HAZEL GAUDET. The People's Choice: How the Voter Makes up His Mind in a Presidential Campaign. (Second Edition.) Pp. xxxiii, 178. New York: Columbia University Press, 1948. \$2.75. The Annals of the American Academy of Political and Social Science, 261, 194-194. https://doi.org/10.1177/000271624926100137

[6] Klapper, J.T. (2014) The Effects of Mass Communication. Social Forces, 40, 98.

[7] Katz, H.E., Bao, Z. and Gilat, S.L. (2001) Synthetic Chemistry for Ultrapure, Processable, and High-Mobility Organic Transistor Semiconductors. Accounts of Chemical Research, 34, 359-369. https://doi.org/10.1021/ar990114j

[8] Livingstone, S. (1997) The Work of Elihu Katz. In: Corner, J., Schlesinger, P. and Silverstone, R., Eds., International Handbook of Media Research, Routledge, London, 18-47.

[9] Derville, G. (2017) The Power of the Media. 4th Edition, Presses Universitaires de Grenoble, Grenoble.

[10] McCombs, M. and Shaw, D. (1991) The Agenda-Setting Function of Mass Media. In: Agenda Setting. Readings on Media, Public Opinion and Policymaking, Lawrence Erlbaum, Hillsdale, 17-26. 
[11] Katz, D. and Suchey, J.M. (1989) Race Differences in Pubic Symphyseal Aging Patterns in the Male. American Journal of Physical Anthropology, 80, 167-172. https://doi.org/10.1002/ajpa.1330800204

[12] Pierchon, F., Pasquier, G., Cotien, A., Fontaine, C., Clarisse, J. and Duquennoy, A. (1994) Causes of Dislocation of Total Hip Arthroplasty. Journal of Bone and Joint Surgery, 76, 45-48. https://doi.org/10.1302/0301-620X.76B1.8300680

[13] UNICEF (2010) Preventing Mother-to-Child Transmission (PMTCT) of HIV Factsheets on the Status of National PMTCT Responses in the Most Affected Countries.

[14] Krosnick, J.A. and Kinder, D.R. (1990) Altering the Foundations of Support for the President through Priming. American Political Science Review, 84, 497-512. https://doi.org/10.2307/1963531

[15] Haase, J., Ge, M., Vedel, H. and Calais, E. (2003) Accuracy and Variability of GPS Tropospheric Delay Measurements of Water Vapor in the Western Mediterranean. Journal of Applied Meteorology, 42, 1547-1568. https://doi.org/10.1175/1520-0450(2003)042<1547:AAVOGT >2.0.CO;2

[16] Pellegrino, P. E. C., Application, F. and Data, P. (1995) United States Patent 19.

[17] Kenny, D.A. (2018) Curriculum vitae.

[18] Dominick, K.L., Ahern, F.M., Gold, C.H. and Heller, D.A. (2002) Relationship of Health-Related Quality of Life to Health Care Utilization and Mortality among Older Adults. Aging Clinical and Experimental Research, 14, 499-508. https://doi.org/10.1007/BF03327351

[19] Gilboa, B.E. (2002) Global Communication and Foreign Policy. Journal of Communication, 52, 731-748. https://doi.org/10.1111/j.1460-2466.2002.tb02571.x

[20] Jakobsen, P.V. (2000) Focus on the CNN Effect Misses the Point: The Real Media Impact on Conflict Management Is Invisible and Indirect. Journal of Peace Research, 37, 131-143. https://doi.org/10.1177/0022343300037002001

[21] Galtung, J. (2004) Imagining Global Democracy. Development and Change, 35, 1073-1079. https://doi.org/10.1111/j.1467-7660.2004.00395.x

[22] Thompson, S.K. (2002) On Sampling and Experiments. Environmetrics, 13, 429-436. https://doi.org/10.1002/env.532

[23] Melone, S.D. and Terzis, G. Beleli, O. (2002) Using the Media for Conflict Transformation: The Common Ground Experience. In: Berghof Handbook for Conflict Transformation, Berghof Research Center for Constructive Conflict Management, Berlin, 1-15.

[24] Ukka, I.T.I. and Kombate, B. (2019) A Research on the Role Played by Local and International Media into Conflict. International Journal of Applied Research in Social Sciences, 1, 41-55.

[25] Hayes, A. (2013) Process Model Templates.

[26] Baron, R.M. and Kenny, D.A. (1986) The Moderator-Mediator Variable Distinction in Social Psychological Research: Conceptual, Strategic, and Statistical Considerations. Journal of Personality and Social Psychology, 51, 1173-1182. https://doi.org/10.1037//0022-3514.51.6.1173

[27] Judd, C.M. and Kenny, D.A. (1981) Process Analysis: Estimating Mediation in Treatment Evaluations. Evaluation Review, 5, 602-619. https://doi.org/10.1177/0193841X8100500502

[28] James, L.R. and Brett, J.M. (1984) Mediators, Moderators, and Tests for Mediation. Journal of Applied Psychology, 69, 307-321. https://doi.org/10.1037//0021-9010.69.2.307 
[29] Hallin, D.C. and Mancini, P. (2004) Comparing Media Systems: Three Models of Media and Politics. Cambridge University Press, Cambridge.

https://doi.org/10.1017/CBO9780511790867 